\title{
Changes of quality traits and phytochemical components of jujube fruit treated with preharvest GA 3 and Parka during cold storage
}

\author{
Orhan Karakaya (D) 1* Erdal Aglar (D) 2*, Burhan Ozturk (D) ${ }^{1}$, Sefa Gun (D) ${ }^{1}$, Umut Ates (D) 1 , \\ Osman Nuri Ocalan (iD 3 \\ ${ }^{1}$ Ordu University, Faculty of Agriculture, Department of Horticulture, Ordu-Turkey \\ ${ }^{2}$ Sivas Cumhuriyet University, Susehri Timur Karabal Vocational School, Sivas-Turkey \\ ${ }^{3}$ Tokat Gaziosmanpaşa University, Faculty of Agriculture, Department of Horticulture, Tokat-Turkey
}

\begin{abstract}
The study aimed to assess the effects of pre-harvest gibberellic acid $\left(\mathrm{GA}_{3}\right)$ and Parka applications on fruit quality and bioactive components of jujube (Ziziphus jujuba Mill. cv. ' $\mathrm{Li}$ ') fruit during the storage. Fruit were kept at $0 \pm 0.5^{\circ} \mathrm{C}$ and $90 \pm 5 \% \mathrm{RH}$ for 45 days. Parka and $\mathrm{GA}_{3}$ applications delayed weight losses and respiration rate in the cold storage. While the effect of the Parka application on the decrease in fruit firmness values depending on the storage time was not significant, it can be said that $\mathrm{GA}_{3}$ application was effective in maintaining the fruit firmness in the cold storage. The increase in soluble solids content (SSC) during cold storage was less with $\mathrm{GA}_{3}$ application. The decrease in titratable acidity with ripening in the cold storage was similar in the Parka and control applications. It can be said that $\mathrm{GA}_{3}$ application was effective in maintaining the titratable acidity during storage and this effect increased with the combination of Parka+GA $\mathrm{G}_{3}$. The highest vitamin $\mathrm{C}$ at the end of the storage was recorded in fruit treated with Parka. Total phenolics, total flavonoids and antioxidant activity decreased in all applications during the storage. $\mathrm{GA}_{3}$ and Parka applications retarded the losses in total phenolics, total flavonoids and antioxidant activity in the storage. As a result, it can be said that the pre-harvest $\mathrm{GA}_{3}$ and Parka applications give positive results in maintaining the quality properties of jujube fruit in the cold storage.
\end{abstract}

\section{ARTICLE HISTORY}

Received: 19 August 2020

Accepted: 8 September 2020

\section{KEYWORDS}

Antioxidant

Color

Flavonoids

Phenolics

Respiration rate

Weight loss

\section{* CORRESPONDING}

orhankarakaya7@gmail.com erdalaglar@gmail.com

\section{Introduction}

Jujube plays a significant role in the treatment of some diseases such as anemia, cancer and heart (Gao et al., 2013), preventing oxidative stress ( $\mathrm{Wu}$ et al., 2013) and strengthening the immune system (Yu et al., 2012; Pu et al., 2018). Along with these traits, it is a fruit species that is preferred by consumers due to its high vitamin $\mathrm{C}$, taste and flavour, and its production is increasing day by day (San and Yildirim, 2010; Yao, 2013; Gunduz and Saracoglu, 2014; Keles, 2020). Jujube, which can be consumed in dried, it is also often consumed fresh in Turkey (Ozturk et al., 2018). It is significant to have a long marketing period in fresh consumption. Although jujube is a non-climatic fruit species with low physiological activity, some physiological disorders such as postharvest decay, dehydration, softening and browning of fruit flesh restrict the storage life of jujube and decrease its market value (Siddiq and Uebersax, 2012). Therefore, it is significant to delay or reduce fruit softening during marketing, transportation and storage, delay physicochemical changes and prevent fruit quality at postharvest. In order to maintain postharvest fruit quality in jujube, the postharvest treatments such as modified atmosphere packaging (Lin et al., 2004), Aleo vera, chitosan coating (Qiuping and Wenshui, 2007), trisodium phosphate, dipping into calcium chloride solution and 1-MCP (1 methylcyclopropene) are made (Gupta et al., 1987; Chen et al., 2019a; Zhang et al., 2019a; Zhang et al., 2019b).

The pre-harvest applications, which will increase the quality and firmness of the fruit, in extending the postharvest storage life play a significant role. In this sense, GA3, which improves the fruit quality by promoting cell growth and elongation (Pharis and King, 1985) and increases fruit firmness with its effect on the cell wall (Fortes et al., 2015), is used effectively to extend the post-harvest life in many fruit species (Einhorn et al., 2013; Sharma and Pratima, 2018). It has been reported that with the pre-harvest $\mathrm{GA}_{3}$ application in jujube, the fruit that had higher firmness values and respiration rate were obtained (Ozturk et al., 2018). It was observed that with the application of Parka (1\% calcium, $5 \%$ cellulose and $7.5 \%$ stearic acid) which prevents water intake by forming a layer on the fruit, limits gas permeability and increases skin elasticity (Meland et al., 2014), jujube (Ozturk et al., 2018) and in sweet cherry (Aglar et al., 2017) fruit cracking was reduced and the fruit were more firmness and had lower respiration rate. The main objective of the study planned by considering the positive 
effects of $\mathrm{GA}_{3}$ and Parka applications on respiration rate and fruit firmness, which are two significant properties in maintaining quality in storage, to assess the role of the $\mathrm{GA}_{3}$ and Parka sprays on quality traits and bioactive compounds in postharvest storage in jujube.

\section{Materials and methods}

\subsection{Plant material}

In the research, trees belonging to 4-year-old ' $\mathrm{Li}$ ' jujube fruit (Ziziphus jujuba Mill. Li) were selected as the plant material. Cultural applications such as irrigation, fertilization and pruning were carried out regularly in trial trees. Trees are pruned as the central leader system.

\subsection{Experimental design}

The experiment was designed to have 3 blocks (replicate) and 16 trees were selected for each replication. In the trail, 4 applications were made as control (only water + surfactant), Parka [(1\%, Cultiva, USA)], gibberellic acid $\left(\mathrm{GA}_{3}, 15 \mathrm{mgL}\right.$ ${ }^{1}$, Valentbioscience, USA) and $\mathrm{GA}_{3}+$ Parka. The solution for each application was sprayed 4 trees on each replicate 3 and 2 weeks before the anticipated harvest (8 October, 2016). Sylgard-309 surfactant (0.05\%, Dow Corning, Canada) was added to the solutions of the applications. 1 tree between the applications has been designed as a buffer tree. Applications were made in the time when a windless is and no rain, in the early morning. At the estimated harvest date, the fruit (25$50 \%$ from yellow / green skin color to red surface color) were harvested by hand, placed in plastic containers of $5 \mathrm{~kg}$ and transferred to the laboratory with a refrigerated vehicle within $4 \mathrm{~h}$. The injured, crushed, cracked and defective fruit were selected and discarded. Then, for each application, the fruit were placed in 9 different plastic boxes, each containing approximately $1 \mathrm{~kg}$ of fruit. Fruit of all applications were placed in modified atmosphere packaging [MAP, StePac, Turkey)] with $1 \mathrm{~kg}$ capacity. Jujube fruit were pre-cooled with cold air for $24 \mathrm{~h}$ at $4 \pm 0.5{ }^{\circ} \mathrm{C}$ and $90 \pm 5 \% \mathrm{RH}$. Then fruit were kept at $0 \pm 0.5{ }^{\circ} \mathrm{C}$ and $90 \pm 5 \% \mathrm{RH}$ for $45 \mathrm{~d}$. Measurements were carried out on days $15^{\text {th }}, 30^{\text {th }}$ and $45^{\text {th }}$ at the cold storage. In each measurement period, 3 boxes were taken for each application. Each box represented a repeat.

\subsection{Weight loss}

Initially, at the starting of storage, first weights of the fruit were measured by a digital scale with a precision of $0.01 \mathrm{~g}$ (Radwag, Poland). Then, on $15^{\text {th }}, 30^{\text {th }}$ and $45^{\text {th }} \mathrm{d}$ of the storage, final weights were determined. The weight loss that occurs in fruit was based on the weight at the beginning of each measurement period.

\subsection{Color characteristics, firmness and respiration rate}

$\mathrm{L}^{*}$, chroma and hue angles were measured in 10 fruit by a colorimeter. CIE (Commission Internationale de l'Eclairage system) was used in color measurements. Then, the X, Y, Z values were converted into $L^{*}, a^{*}$ and $b^{*}$ coordinates. The equations of $C^{*}=\left(a^{* 2}+b^{* 2}\right)^{1 / 2}$ for chroma and $h^{\circ}=\tan ^{-1} b^{*} / a^{*}$ for hue angle were used. To determine the fruit firmness (10 fruit), digital firmness tester (Agrosta ${ }^{\circledR}$ 100, France) was used. The scale ranges from 0 to 100 for very soft to very firm surfaces. To measure respiration rates, $2 \mathrm{~L}$ airtight chambers were fitted with a rubber septum and 4 fruit were sealed in each chamber at $20 \pm 1{ }^{\circ} \mathrm{C}$ temperature and $80 \% \mathrm{RH}$ for $1 \mathrm{~h}$. The chambers were then connected to a gas sensor (Vernier, USA) and the amount of $\mathrm{CO}_{2}$ produced by the fruit was considered as the respiration rate. Results were stated in $\mathrm{mL} \mathrm{CO} \mathrm{kg}^{-1} \mathrm{~h}^{-1}$.

\subsection{Vitamin C, titratable acidity (TA) and soluble solids content (SSC)}

For vitamin $\mathrm{C}$ measurements, $0.5 \mathrm{~mL}$ juice was taken, and 5 $\mathrm{mL}$ of $0.5 \%$ oxalic acid was added on it. The ascorbic acid test strip (Merck, Germany) was taken from a collapsible sealed gas-tight tube. Reflectometer (Merck RQflex plus 10) was started. The test strip was plunged into the solution for 2 seconds, and then removed from the solution. It was then held for 8 seconds, and reading was done at the end of the $15^{\text {th }}$ second. Results were presented as $\mathrm{mg} 100 \mathrm{~g}^{-1}$. For titratable acidity measurements, $10 \mathrm{~mL}$ juice was taken and $10 \mathrm{~mL}$ distilled water was added on. Then $0.1 \mathrm{~N} \mathrm{NaOH}$ (sodium hydroxide) was added until the $\mathrm{pH}$ of the solution reached to 8.2. Based on the amount of $\mathrm{NaOH}$ consumed in titration, acidity was determined and expressed as g malic acid $100 \mathrm{~mL}^{-1}$. SSC was measured with a portable digital refractometer (Atago PAL-1, USA) and expressed as \%.

\subsection{Bioactive compounds}

During each measurement period, 5 fruit were taken from each replication of each treatment. The fruit were washed with distilled water, and sliced with a stainless steel knife. Later, the fruit pulp was crumbled by a blender, and homogenized. About $30 \mathrm{~mL}$ of homogenate was taken and placed into $50 \mathrm{ml}$ falcon tubes. The tubes were kept at $-20^{\circ} \mathrm{C}$ until the analyses.

Before the analyses, the frozen samples were dissolved under room temperature $\left(21^{\circ} \mathrm{C}\right)$. Pulp and juice were separated from each other by a centrifuge at $12.000 \times \mathrm{g}$ at 4 ${ }^{\circ} \mathrm{C}$ for $35 \mathrm{~min}$. The resultant filtrate was used to determine total phenolics, total flavonoids and antioxidant activity of the samples.

Spectrophotometric measurements for bioactive compounds were performed in a UV-Vis spectrophotometer (Shimadzu, Kyoto, Japan). Total phenolics was measured according to the method described by Beyhan et al. (2010), and was expressed as mg gallic acid equivalent (GAE) 100 $\mathrm{g}^{-1}$ fw. Total flavonoids was measured according to the method of Chang et al. (2002) and was expressed as mg quercetin equivalent (QE) $100 \mathrm{~g}^{-1} \mathrm{fw}$.

The antioxidant activity of jujube fruit was determined according to two different procedures of 1.1-diphenyl-2picryl-hydrazil (DPPH) (Blois, 1958) and Ferric Ions $\left(\mathrm{Fe}^{+3}\right)$ Reducing Antioxidant Power (FRAP) (Benzie and Strain, 1996), and the results were expressed as mmol in $100 \mathrm{~g}^{-1}$ Trolox equivalent (TE) fw.

\subsection{Statistical analysis}

Whether the data was normally distributed was checked by Kolmogrov-Smirnov Test. Homogeneity of variances was confirmed by Levene's test. After the variance analysis of the data, Tukey's multiple-comparison test was used to check whether there were significant differences $(\mathrm{P}<0.05)$ between treatments. The statistical analyses were performed by using SAS software (SAS 9.1 version, USA). 


\section{Results and discussion}

\subsection{Weight loss}

The weight loss that occurs in the storage causes great economic losses. In some species, weight loss can be up to 25-30\% (Sandhya, 2010; Chen et al., 2019b). Loss of weight in fruit is directly related to the loss of water caused by transpiration, which varies depending on the surface volume ratio of the fruit and the relative humidity of the storage atmosphere (Kader and Yahia, 2011). In the study, the weight loss occurred in the fruit of control application at the end of the cold storage was $1.83 \%$. Parka and $\mathrm{GA}_{3}$ applications reduced weight losses in the cold storage. There was no difference in effect between the Parka and $\mathrm{GA}_{3}$ applications (Table 1). It is likely to be lower the loss of weight with the application of Parka (Meland et al., 2014), which creates a layer on the fruit and limits water intake. Similarly, Valero et al. (2014) stated that the application of Aleo vera coating limited the water loss in fruit, thereby reducing the weight loss in storage. $\mathrm{GA}_{3}$ application in different fruit species has positive effects on decreasing of the weight loss (Sharma and Pratima, 2018). The significant role of gibberellic acid (Fortes et al., 2015) in the formation and structure of the cuticle layer of the fruit may be the reason for the reduction in weight loss in the cold storage. However, Aglar et al. (2017) reported that the Parka application had no effect on the weight losses that occurred during storage in sweet cherry.

Table 1. Weight loss of preharvest $\mathrm{GA}_{3}$ and Parka-treated jujube fruit during storage at $0 \pm 0.5^{\circ} \mathrm{C}$ and $90 \pm 5 \% \mathrm{RH}$

\begin{tabular}{lccc}
\hline Treatments & \multicolumn{3}{c}{ Weight loss $(\%)$} \\
\cline { 2 - 4 } & 15 day & 30 day & 45 day \\
\hline Control & $0.68 \mathrm{a}$ & $1.63 \mathrm{a}$ & $1.83 \mathrm{a}$ \\
Parka & $0.28 \mathrm{~b}$ & $1.30 \mathrm{~b}$ & $1.55 \mathrm{~b}$ \\
$\mathrm{GA}_{3}$ & $0.38 \mathrm{~b}$ & $1.36 \mathrm{~b}$ & $1.56 \mathrm{~b}$ \\
Parka+GA & $0.33 \mathrm{~b}$ & $1.33 \mathrm{~b}$ & $1.53 \mathrm{~b}$ \\
\hline
\end{tabular}

Means in columns with the same letter do not differ according to Tukey's test at $\mathrm{P}<0.05$.

\subsection{Respiration rate}

At the harvest, there was no statistically significant difference between the respiration rates of the fruit of control and Parka application and $\mathrm{GA}_{3}$-treated fruit had a lower respiration rate (Table 2). However, Ozturk et al. (2018) reported that fruit with higher respiration rate were obtained with $\mathrm{GA}_{3}$ and Parka application in jujube. Respiration, which determines the postharvest life time by affecting the energy mechanism in the fruit, contains a series of oxidationreduction reactions and the consumption of sugar and organic acid as the substrate (Chumyam et al., 2017).

Table 2. Respiration rate and firmness of preharvest $\mathrm{GA}_{3}$ and Parka-treated jujube fruit during storage at $0 \pm 0.5^{\circ} \mathrm{C}$ and 90 $\pm 5 \% \mathrm{RH}$

\begin{tabular}{llllll}
\hline \multirow{2}{*}{$\begin{array}{l}\text { Quality } \\
\text { characteristics }\end{array}$} & Treatments & \multicolumn{4}{c}{ Storage time } \\
\cline { 2 - 5 } & & Harvest & 15 day & 30 day & 45 day \\
\hline \multirow{2}{*}{$\begin{array}{l}\text { Respiration rate } \\
\left(\mathrm{mL} \mathrm{CO}_{2} \mathrm{~kg}^{-1} \mathrm{~h}^{-1}\right)\end{array}$} & Control & $40.27 \mathrm{a}$ & $39.34 \mathrm{~b}$ & $74.19 \mathrm{a}$ & $55.33 \mathrm{a}$ \\
& Parka & $45.08 \mathrm{a}$ & $54.78 \mathrm{a}$ & $56.63 \mathrm{~b}$ & $41.22 \mathrm{~b}$ \\
& $\mathrm{GA}_{3}$ & $22.09 \mathrm{~b}$ & $33.14 \mathrm{c}$ & $35.91 \mathrm{c}$ & $29.64 \mathrm{c}$ \\
& Parka+GA & $26.26 \mathrm{~b}$ & $29.10 \mathrm{c}$ & $34.85 \mathrm{c}$ & $24.51 \mathrm{c}$ \\
\hline \multirow{3}{*}{ Firmness $\left(^{*}\right)$} & Control & $87.78 \mathrm{a}$ & $74.11 \mathrm{a}$ & $67.54 \mathrm{~b}$ & $64.81 \mathrm{~b}$ \\
& Parka & $88.96 \mathrm{a}$ & $75.25 \mathrm{a}$ & $66.89 \mathrm{~b}$ & $63.19 \mathrm{~b}$ \\
& $\mathrm{GA}_{3}$ & $81.33 \mathrm{~b}$ & $74.60 \mathrm{a}$ & $65.37 \mathrm{~b}$ & $64.30 \mathrm{~b}$ \\
& Parka+GA $_{3}$ & $82.50 \mathrm{~b}$ & $75.30 \mathrm{a}$ & $73.03 \mathrm{a}$ & $67.60 \mathrm{a}$ \\
\hline
\end{tabular}

* The scale ranges from 0 to 100 for very soft to very firm surfaces. Means in columns with the same letter do not differ according to Tukey's test at $\mathrm{P}<0.05$.

In jujube, which shows a non-climacteric respiration structure in cold storage (Sheng et al., 2003), an increase in respiration rate occurs depending on the storage time (Zhao et al., 2020). The changes occurred the respiration rate of all applications during the cold storage was significant. At the $15^{\text {th }}$ day of the cold storage, the lower respiration rate was measured compared to the value measured at harvest while the respiration rate increased in $30^{\text {th }}$ day, and decreased again in $45^{\text {th }}$ day. Parka-applied fruit had the highest respiration rate on the $15^{\text {th }}$ day of the cold storage, but on other measurement days, the highest values were recorded with the control application. Parka and $\mathrm{GA}_{3}$ applications reduced the respiration rate of fruit while the lowest values were measured with $\mathrm{GA}_{3}$ application. In terms of the effect, the significant differences between Parka and $\mathrm{GA}_{3}$ application occurred. However, the differences between the respiration rate values of $\mathrm{GA}_{3}$ and Parka+GA 3 applications were not significant (Table 2). $\mathrm{GA}_{3}$ plays significant role on certain biological processes including respiration in the plant (Pharis and King, 1985). GA 3 is used effectively to prolong postharvest life in many fruit species (Einhorn et al., 2013; Sharma and Pratima, 2018). Edible coating applications such as Parka (Meland et al., 2014), Aloe vera (AV) and chitosan (Mahajan et al., 2018) reduce respiration rate by limiting 
oxygen and carbondioxide gas transfer. With AV application, the ripening in fruit species such as pomegranate arils (Martínez-Romero et al., 2013), kiwifruit (Benitez et al., 2013), grapes (Chauhan et al., 2014) and raspberry fruit (Hassanpour, 2015) delayed.

\subsection{Fruit firmness}

Pre-harvest Parka application had no effect on the fruit firmness. The fruit with lower firmness value in $\mathrm{GA}_{3}$ treated trees were harvested (Table 2). However, Einhorn et al. (2013) reported that by using $\mathrm{GA}_{3}$, the fruit, which had higher fruit firmness, can be obtained. Choi et al. (2002); Clayton et al. (2006) and Correia et al. (2019) reported that $\mathrm{GA}_{3}$ application in sweet cherry increased fruit firmness, but it has been suggested that $\mathrm{GA}_{3}$ applications do not affect the fruit firmness in jujube (Ozturk et al., 2018) and grapes (Alrashidi et al., 2017). Again, it has been reported that with the application of Parka, fruit harvested in sweet cherry (Aglar et al., 2017) and jujube (Ozturk et al., 2018) have higher fruit firmness value. While the effect of Parka application on the decrease in fruit firmness values depending on the storage time was not significant, it can be said that $\mathrm{GA}_{3}$ application is effective in maintaining the fruit firmness in cold storage.

In the control application, the fruit firmness, which was determined as $87.78 \%$ at harvest, became $64.81 \%$ by decreasing $22.97 \%$ on 45 days after the storage. However, the decrease in storage time with the $\mathrm{GA}_{3}$ application was $17.01 \%$. Again, at $30^{\text {th }}$ and $45^{\text {th }}$ days of storage, the highest fruit firmness values were recorded with Parka $+\mathrm{GA}_{3}$ application (Table 2). It can be said that the effect of this application is caused by $\mathrm{GA}_{3}$. $\mathrm{GA}_{3}$, which promotes cell division and growth (Pharis and King, 1985), can be effective in maintaining fruit firmness during storage due to its effect on the cell wall (Fortes et al., 2015). Indeed, Souza et al. (2016) in cashew apple, $\mathrm{GA}_{3}$-treated fruit had higher fruit firmness values during storage; Ozkan et al. (2016), on the other hand, suggested that fruit with high firmness values were obtained with $\mathrm{GA}_{3}$ application and the effect of $\mathrm{GA}_{3}$ application was significant in maintaining these values during storage. Edible coating applications such as Parka, chitosan and Aleo vera delay maturation by decreasing cell wall enzyme activity (Khaliq et al., 2019) and oxygen uptake (Cha and Chinnan, 2004), and maintain cell turgor pressure by limiting transpiration (Mannozzi et al., 2018). Aglar et al. (2017) reported that in the $21^{\text {st }}$ day of cold storage in sweet cherry, the fruit applied to the Parka had higher fruit firmness.

\subsection{Color characteristics}

In the measurements performed at the harvest, when the effect of Parka and $\mathrm{GA}_{3}$ applications on fruit color was evaluated, it was determined that the application of Parka caused a decrease in the $\mathrm{L}$ value of the fruit, but its effect on the Chroma and Hue angle values was not significant. $\mathrm{GA}_{3}$ application affected all three values (L, chroma and hue angle), and with this application, fruit with low $\mathrm{L}$ and hue angle values and high chroma values were obtained (Table 3). However, Ozturk et al. (2018), in their study, reported that the Parka application did not affect the color of fruit in jujube. The occurrence of color loss, which is one of the symptoms of environmental stress and senescence in the fruit, can be prevented by cold storage, but the loss of color accelerates with prolonged storage time (Han et al., 2017). In the study in accordance with this explanation, it was found that the color loss increased with prolonged storage period (Table 3).

Table 3. Color characteristics ( $\mathrm{L}^{*}$, chroma and hue angle) of preharvest $\mathrm{GA}_{3}$ and Parka-treated jujube fruit during storage at $0 \pm 0.5^{\circ} \mathrm{C}$ and $90 \pm 5 \% \mathrm{RH}$

\begin{tabular}{|c|c|c|c|c|c|}
\hline \multirow{2}{*}{$\begin{array}{l}\text { Quality } \\
\text { characteristics }\end{array}$} & \multirow[t]{2}{*}{ Treatments } & \multicolumn{4}{|c|}{ Storage time } \\
\hline & & Harvest & 15 day & 30 day & 45 day \\
\hline \multirow{4}{*}{$\mathrm{L}^{*}$} & Control & $86.45 \mathrm{a}$ & $63.47 \mathrm{~b}$ & $58.19 \mathrm{~b}$ & $50.73 \mathrm{c}$ \\
\hline & Parka & $83.96 \mathrm{~b}$ & $60.65 \mathrm{c}$ & $51.75 \mathrm{c}$ & $43.32 \mathrm{~d}$ \\
\hline & $\mathrm{GA}_{3}$ & $84.44 b$ & $59.51 \mathrm{c}$ & $58.14 b$ & $56.55 \mathrm{~b}$ \\
\hline & Parka+GA 3 & $84.20 \mathrm{~b}$ & $69.76 \mathrm{a}$ & $64.38 \mathrm{a}$ & $64.11 \mathrm{a}$ \\
\hline \multirow{4}{*}{ Chroma } & Control & $41.05 \mathrm{~b}$ & $48.17 \mathrm{a}$ & $50.82 \mathrm{a}$ & $51.16 \mathrm{a}$ \\
\hline & Parka & $42.15 \mathrm{~b}$ & $47.26 \mathrm{a}$ & $49.16 \mathrm{a}$ & $51.89 \mathrm{a}$ \\
\hline & $\mathrm{GA}_{3}$ & $45.50 \mathrm{a}$ & $45.62 \mathrm{~b}$ & $47.26 \mathrm{~b}$ & $47.70 \mathrm{~b}$ \\
\hline & Parka+GA 3 & $42.95 \mathrm{~b}$ & $47.14 \mathrm{a}$ & $47.42 \mathrm{~b}$ & $47.63 \mathrm{~b}$ \\
\hline \multirow{4}{*}{ Hue angle } & Control & $90.19 \mathrm{~b}$ & $72.07 \mathrm{c}$ & $69.65 \mathrm{c}$ & $64.55 \mathrm{~b}$ \\
\hline & Parka & $89.26 \mathrm{~b}$ & $73.13 \mathrm{c}$ & $63.63 \mathrm{~d}$ & $60.16 \mathrm{c}$ \\
\hline & $\mathrm{GA}_{3}$ & $86.12 \mathrm{c}$ & $82.88 \mathrm{~b}$ & $81.95 \mathrm{~b}$ & $80.78 \mathrm{a}$ \\
\hline & Parka+GA 3 & $96.69 \mathrm{a}$ & $89.25 \mathrm{a}$ & $87.71 \mathrm{a}$ & $83.34 \mathrm{a}$ \\
\hline
\end{tabular}

Means in columns with the same letter do not differ according to Tukey's test at $\mathrm{P}<0.05$.

$\mathrm{GA}_{3}$ application may decrease color loss because it delays to anthocyanin degradation (Zhao et al., 2020). While L and hue angle values decreased during storage, this decrease was higher in Parka application. $\mathrm{GA}_{3}$ application had a positive effect on maintaining these two values. Fruit chroma value increased depending on storage time and the effect of Parka application on chroma value was not significant. However, the increase in chroma value was lower in $\mathrm{GA}_{3}$ application (Table 3). Dong et al. (2019) have determined that $\mathrm{GA}_{3}$ application delays fruit color change during the cold storage in sweet cherry. Coating materials affect fruit coloring because they cause changes in fruit surface properties and 
limit the ripening process (Hoagland and Parris, 1996). In studies conducted, it has been reported that the coating applications such as alginate (Chiabrando and Giacalone, 2015) and Parka (Aglar et al., 2017) in sweet cherry and AV in mango (Carrillo-Lopez et al., 2000) decreased color changes in fruit after harvest.

\subsection{Soluble solids content, titratable acidity and vitamin $C$}

With the Parka and $\mathrm{GA}_{3}$ applications, fruit with a lower SSC were obtained (Table 4). Ozturk et al. (2018) obtained similar results with the application of $\mathrm{GA}_{3}$ and Parka in jujube. Einhorn et al. (2013) suggested that SSC increased with $\mathrm{GA}_{3}$ application in sweet cherry, but Ozkan et al. (2016) determined that it decreased. Alrashdi et al. (2017) reported that $\mathrm{GA}_{3}$ application did not affect SSC content in grapes. With prolonged storage time, the rate of SSC in fruit increased (Table 4). SSC, which is one of the fruit harvest criteria, increases as a result of hydrolysis of undissolved polysaccharides in simple sugars and increased metabolic activities together with prolonging of maturity progresses (Hassanpour, 2015).

Table 4. Soluble solids content (SSC), titratable acidity and vitamin $\mathrm{C}$ of preharvest $\mathrm{GA}_{3}$ and Parka-treated jujube fruit during storage at $0 \pm 0.5^{\circ} \mathrm{C}$ and $90 \pm 5 \% \mathrm{RH}$

\begin{tabular}{llcccc}
\hline \multirow{2}{*}{$\begin{array}{l}\text { Quality } \\
\text { characteristics }\end{array}$} & Treatments & \multicolumn{4}{c}{ Storage time } \\
\cline { 2 - 5 } SSC & & Harvest & 15 day & 30 day & 45 day \\
\hline & Control & $21.20 \mathrm{a}$ & $23.45 \mathrm{a}$ & $24.80 \mathrm{a}$ & $25.85 \mathrm{a}$ \\
& Parka & $20.25 \mathrm{~b}$ & $21.55 \mathrm{~b}$ & $24.52 \mathrm{a}$ & $25.37 \mathrm{a}$ \\
& $\mathrm{GA}_{3}$ & $20.21 \mathrm{~b}$ & $21.80 \mathrm{~b}$ & $22.03 \mathrm{~b}$ & $23.27 \mathrm{~b}$ \\
& Parka+GA & $20.50 \mathrm{~b}$ & $21.57 \mathrm{~b}$ & $22.30 \mathrm{~b}$ & $23.97 \mathrm{~b}$ \\
\hline \multirow{3}{*}{ Titratable acidity } & Control & $0.30 \mathrm{~b}$ & $0.25 \mathrm{c}$ & $0.24 \mathrm{c}$ & $0.22 \mathrm{c}$ \\
$\left(\mathrm{g}\right.$ malic acid $\left.100 \mathrm{~mL}^{-1}\right)$ & Parka & $0.29 \mathrm{~b}$ & $0.25 \mathrm{c}$ & $0.23 \mathrm{c}$ & $0.20 \mathrm{c}$ \\
& $\mathrm{GA}_{3}$ & $0.33 \mathrm{a}$ & $0.28 \mathrm{~b}$ & $0.28 \mathrm{~b}$ & $0.27 \mathrm{~b}$ \\
& Parka+GA $_{3}$ & $0.32 \mathrm{a}$ & $0.32 \mathrm{a}$ & $0.30 \mathrm{a}$ & $0.29 \mathrm{a}$ \\
\hline \multirow{3}{*}{ Vitamin C } & Control & $267.5 \mathrm{~b}$ & $245.0 \mathrm{~b}$ & $206.5 \mathrm{~d}$ & $202.0 \mathrm{~b}$ \\
$\left(\mathrm{mg} 100 \mathrm{~g}^{-1}\right)$ & Parka & $285.6 \mathrm{a}$ & $260.0 \mathrm{a}$ & $245.6 \mathrm{a}$ & $214.5 \mathrm{a}$ \\
& $\mathrm{GA}_{3}$ & $258.3 \mathrm{~b}$ & $245.3 \mathrm{~b}$ & $230.5 \mathrm{~b}$ & $195.3 \mathrm{~b}$ \\
& Parka+GA $_{3}$ & $230.3 \mathrm{c}$ & $222.0 \mathrm{c}$ & $220.0 \mathrm{c}$ & $217.0 \mathrm{a}$ \\
\hline
\end{tabular}

Means in columns with the same letter do not differ according to Tukey's test at $\mathrm{P}<0.05$.

The increase in SSC rate during storage was less with $\mathrm{GA}_{3}$ application. Parka-treated fruit on $15^{\text {th }}$ day of the cold storage had a lower SSC compared to control, while there was no difference between control and Parka applications on other measurement days (Table 4). Aglar et al. (2017), in their study on sweet cherry, suggested that the rate of SSC was lower in the Parka-treated fruit during storage period. Zhao et al. (2020) reported that the rate of SSC reached peak after 3 days of the cold storage in $\mathrm{GA}_{3}$-applied fruit. With the $\mathrm{GA}_{3}$ application, it was determined that the rate of titratable acidity in the fruit increased, and Parka application had no effect on titratable acidity. The reduction in titratable acidity rate with maturation in storage was similar in the Parka and control applications. It can be said that $\mathrm{GA}_{3}$ application was effective in maintaining the titratable acidity ratio during cold storage, and this effect increased with the combination of Parka $+\mathrm{GA}_{3}$ (Table 4). The acidity rate in fruit at harvest is the highest level, but it decreases as ripening progresses (Reque et al., 2014). Bahmani et al. (2015) stated that the rate of titratable acidity in the fruit decreased due to high respiration after harvest. The coating materials such as Aleo vera (Valverde et al., 2005) and Parka (Aglar et al., 2017) delay the reduction of titratable acidity content by lowering the respiration rate of the fruit at the postharvest storage. Zhao et al. (2020) determined that the rate of titratable acidity was lower with $\mathrm{GA}_{3}$ application in harvested fruit, but the rate of titratable acidity was higher in fruit with $\mathrm{GA}_{3}$ application compared to control in the storage measurements. Dong et al. (2019) reported that fruit treated with pre-harvest $\mathrm{GA}_{3}$ in "Lapins" sweet cherry cultivar had a lower titratable acidity rate after 4 weeks of the cold storage. The difference in the vitamin $\mathrm{C}$ of the fruit with $\mathrm{GA}_{3}$ application did not occurred, but fruit with the highest vitamin $\mathrm{C}$ were obtained with Parka application. Vitamin $\mathrm{C}$ decreased in proportion to the storage time. Although the highest vitamin $\mathrm{C}$ at the end of the cold storage was recorded in Parka-treated fruit, the highest loss of vitamin $\mathrm{C}$ during storage occurred in these fruit. At cold storage, vitamin $\mathrm{C}$ in $\mathrm{GA}_{3}$ and control applications was determined as 63.5 and $65.5 \mathrm{mg} 100 \mathrm{~g}^{-1}$ respectively. It can be said that the application of Parka+ $\mathrm{GA}_{3}$ reduces the loss of the vitamin $\mathrm{C}$ in storage (Table 4). Ozturk et al. (2018) reported that a significant increase in vitamin $\mathrm{C}$ ratio with Parka and $\mathrm{GA}_{3}$ applications in jujube occurred, while Zhao et al. (2020) determined that the decrease in vitamin $\mathrm{C}$ ratio occurred in proportion to the storage period and that at the end of the cold storage, the $\mathrm{GA}_{3}$-treated fruit had a higher vitamin $\mathrm{C}$ compared to the control. Aglar et al. (2017) reported that the application of the pre-harvest Parka in sweet cherry had no effect on the decrease in vitamin $\mathrm{C}$ after $21 \mathrm{~d}$ of the cold storage.

\subsection{Bioactive compounds}

There is a positive correlation between the content of bioactive compounds (Serra et al., 2011) whose concentration varies depending on the genetic and 
environmental factors, and the fruit ripening stage. The concentrations of bioactive compounds such as phenolic substances, anthocyanins and antioxidants at the fruit ripening stage are at the highest level (Mahmood et al., 2013). Diaz-Mula et al. (2009) and Ozkan et al. (2016) suggested that in sweet cherry, $\mathrm{GA}_{3}$-applied fruit had lower total phenolics, antioxidant activity and total anthocyanin content. It was determined that in the harvested fruit, $\mathrm{GA}_{3}$ application had no effect on the total phenolic and it decreased the total flavonoids and increased the antioxidant activity. While the Parka application decreased the total phenolics and antioxidant activity, it had no effect on the flavonoids (Table 5).

Table 5. Total phenolics, total flavonoids and antioxidant activity (FRAP· and DPPH·) of preharvest GA 3 and Parka-treated jujube fruit during storage at $0 \pm 0.5^{\circ} \mathrm{C}$ and $90 \pm 5 \% \mathrm{RH}$

\begin{tabular}{|c|c|c|c|c|c|}
\hline \multirow{2}{*}{$\begin{array}{l}\text { Quality } \\
\text { characteristics }\end{array}$} & \multirow[t]{2}{*}{ Treatments } & \multicolumn{4}{|c|}{ Storage time } \\
\hline & & Harvest & 15 day & 30 day & 45 day \\
\hline \multirow{4}{*}{$\begin{array}{l}\text { Total phenolics } \\
\left(\mathrm{mg} \text { GAE } 100 \mathrm{~g}^{-1} \mathrm{fw}\right)\end{array}$} & Control & $722 \mathrm{a}$ & $596 \mathrm{c}$ & $512 \mathrm{c}$ & $402 \mathrm{c}$ \\
\hline & Parka & $643 \mathrm{~b}$ & $594 \mathrm{c}$ & $557 \mathrm{~b}$ & $513 \mathrm{~b}$ \\
\hline & $\mathrm{GA}_{3}$ & $717 \mathrm{a}$ & $664 \mathrm{a}$ & $603 \mathrm{a}$ & $590 \mathrm{a}$ \\
\hline & Parka+GA 3 & $639 \mathrm{~b}$ & $625 \mathrm{~b}$ & $608 \mathrm{a}$ & $570 \mathrm{a}$ \\
\hline \multirow{4}{*}{$\begin{array}{l}\text { Total flavonoids } \\
\left(\mathrm{mg} \mathrm{QE} \mathrm{g}{ }^{-1} 100 \mathrm{fw}\right)\end{array}$} & Control & $215 \mathrm{a}$ & $146 \mathrm{c}$ & $110 \mathrm{c}$ & $105 \mathrm{c}$ \\
\hline & Parka & $223 \mathrm{a}$ & $168 \mathrm{~b}$ & $129 \mathrm{~b}$ & $115 \mathrm{~b}$ \\
\hline & $\mathrm{GA}_{3}$ & $200 \mathrm{~b}$ & $183 \mathrm{a}$ & $149 \mathrm{a}$ & $138 \mathrm{a}$ \\
\hline & Parka+GA 3 & $185 \mathrm{c}$ & $180 \mathrm{a}$ & $145 \mathrm{a}$ & $141 \mathrm{a}$ \\
\hline \multirow{4}{*}{$\begin{array}{l}\text { FRAP. } \\
\left(\mathrm{mmol} \text { TE } 100 \mathrm{~g}^{-1} \mathrm{fw}\right)\end{array}$} & Control & $61.6 \mathrm{~b}$ & $50.2 \mathrm{~b}$ & $36.6 \mathrm{c}$ & $30.6 \mathrm{c}$ \\
\hline & Parka & $61.1 \mathrm{~b}$ & $44.6 \mathrm{c}$ & $40.2 \mathrm{~b}$ & $36.2 \mathrm{~b}$ \\
\hline & $\mathrm{GA}_{3}$ & $68.3 \mathrm{a}$ & $56.6 \mathrm{a}$ & $45.5 \mathrm{a}$ & $50.6 \mathrm{a}$ \\
\hline & Parka+GA 3 & $67.6 \mathrm{a}$ & $56.5 \mathrm{a}$ & $4.4 .2 \mathrm{a}$ & $53.7 \mathrm{a}$ \\
\hline \multirow{4}{*}{$\begin{array}{l}\text { DPPH· } \\
\left(\mathrm{mmol} \text { TE } 100 \mathrm{~g}^{-1} \mathrm{fw}\right)\end{array}$} & Control & $57.3 \mathrm{~b}$ & $52.4 \mathrm{c}$ & $41.9 \mathrm{c}$ & $33.9 \mathrm{c}$ \\
\hline & Parka & $58.5 \mathrm{~b}$ & $54.6 \mathrm{~b}$ & $46.3 \mathrm{~b}$ & $41.5 \mathrm{~b}$ \\
\hline & $\mathrm{GA}_{3}$ & $60.6 \mathrm{a}$ & $59.6 \mathrm{a}$ & $54.3 \mathrm{a}$ & $52.2 \mathrm{a}$ \\
\hline & Parka+GA 3 & $61.3 \mathrm{a}$ & $58.6 \mathrm{a}$ & $53.9 \mathrm{a}$ & $51.8 \mathrm{a}$ \\
\hline
\end{tabular}

Means in columns with the same letter do not differ according to Tukey's test at $\mathrm{P}<0.05$.

Ozturk et al. (2018) reported that in jujube, Parka application has no effect on total flavonoids, but unlike our study, it increased total phenolics and antioxidant activity. Total phenolics, total flavonoids and antioxidant activity decreased in all applications during storage. $\mathrm{GA}_{3}$ and Parka applications positively affected the losses in total phenolics, total flavonoids and antioxidant activity in storage. The highest values at the end of the cold storage were recorded with $\mathrm{GA}_{3}$ application while the lowest values were obtained with the control application. However, Aglar et al. (2018) found that in sweet cherry, the pre-harvest Parka application had no effect on total phenolics and antioxidant activity during storage.

At the end of the study, it was concluded that higher quality fruit were obtained with pre-harvest $\mathrm{GA}_{3}$ and Parka applications had positive effects in reducing the quality losses in the cold storage. Also, with $\mathrm{GA}_{3}$ and Parka applications, the quality of jujube fruit was maintained until 45 days at $0 \pm 0.5^{\circ} \mathrm{C}$ and $90 \pm 5 \% \mathrm{RH}$.

\section{Authors' Contributions}

Orhan Karakaya: Validation, Writing - original draft. Erdal Aglar: Methodology, Investigation, Conceptualization, Validation, Review and editing. Burhan Ozturk: Methodology, Investigation, Conceptualization, Validation, Writing - original draft, Visualization. Sefa Gun:
Methodology, Investigation, Formal analysis, Data curation. Umut Ates: Formal analysis, Data curation. Osman Nuri Ocalan: Formal analysis, Data curation.

\section{Conflict of Interest}

The authors declare that they have no conflict of interest.

\section{References}

Aglar, E., Ozturk, B., Guler, S. K., Karakaya, O., Uzun, S., \& Saracoglu, O. (2017). Effect of modified atmosphere packaging and 'Parka' treatments on fruit quality characteristics of sweet cherry fruits (Prunus avium L. '0900 Ziraat') during cold storage and shelf life. Scientia Horticulturae, 222, 162-168.

Alrashdi, A. M., Al-Qurashi, A. D., Awad, M. A., Mohamed, S. A., \& Al-rashdi, A. A. (2017). Quality, antioxidant compounds, antioxidant capacity and enzymes activity of 'El-Bayadi' table grapes at harvest as affected by preharvest salicylic acid and gibberellic acid spray. Scientia Horticulturae, 220, 243-249.

Bahmani, M. S., Yusefzadi, M., Hasanzadeh, H., \& Yektankhodaeei, M. (2015). The effect of thyme essential oil, calcium chloride and storage time on quantity and quality of sapodilla fruit (Manilkara zapota L.) var. Oval. International Journal of Agriculture and Crop Sciences, 8, 221-226.

Benítez, M. S., Hersh, M. H., Vilgalys, R., \& Clark, J. S. (2013). Pathogen regulation of plant diversity via effective specialization. Trends in Ecology \& Evolution, 28(12), 705711. 
Benzie, I. F., \& Strain, J. J. (1996). The ferric reducing ability of plasma (FRAP) as a measure of "antioxidant power": the FRAP assay. Analytical Biochemistry, 239(1), 70-76.

Beyhan, Ö., Elmastaş, M., \& Gedikli, F. (2010). Total phenolic compounds and antioxidant capacity of leaf, dry fruit and fresh fruit of feijoa (Acca sellowiana, Myrtaceae). Journal of Medicinal Plants Research, 4(11), 1065-1072.

Blois, M. S. (1958). Antioxidant determinations by the use of a stable free radical. Nature, 181(4617), 1199-1200.

Carrillo-Lopez, A., Ramirez-Bustamante, F., Valdez-Torres, J. B., Rojas-Villegas, R., \& Yahia, E. M. (2000). Ripening and quality changes in mango fruit as affected by coating with an edible film. Journal of Food Quality, 23(5), 479-486.

Cha, D. S., \& Chinnan, M. (2004). Biopolymer-based antimicrobial packaging: a review. Critical Reviews in Food Science and Nutrition, 44, 223-237.

Chang, C. C., Yang, M. H., Wen, H. M., \& Chern, J. C. (2002). Estimation of total flavonoid content in propolis by two complementary colorimetric methods. Journal of food and drug analysis, 10(3).

Chauhan, S., Gupta, K. C., \& Agrawal, M. (2014). Application of Biodegradable Aloe vera gel to control post-harvest decay and longer the shelf life of Grapes. International Journal Current Microbiology and Applied Sciences, 3(3), 632-642.

Chen, H., Sun, Z., \& Yang, H. (2019a). Effect of carnauba waxbased coating containing glycerol monolaurate on the quality maintenance and shelf-life of Indian jujube (Zizyphus mauritiana Lamk.) fruit during storage. Scientia Horticulturae, 244, 157-164.

Chen, Y.H., Hung, Y.C., Chen, M.Y., Lin, M.S., \& Lin, H.T. (2019b). Enhanced storability of blueberries by acidic electrolyzed oxidizing water application may be mediated by regulating ROS metabolism. Food Chemistry, 270, 229-235.

Chiabrando, V., \& Giacalone, G. (2015). Anthocyanins, phenolics and antioxidant capacity after fresh storage of blueberry treated with edible coatings. International Journal of Food Sciences and Nutrition, 66(3), 248-253.

Choi, C., Wiersma, P. A., Toivonen, P., \& Kappel, F. (2002). Fruit growth, firmness and cell wall hydrolytic enzyme activity during development of sweet cherry fruit treated with gibberellic acid $\left(\mathrm{GA}_{3}\right)$. The Journal of Horticultural Science and Biotechnology, 77(5), 615-621.

Chumyam, A., Shank, L., Faiyue, B., Uthaibutra, J., \& Saengnil, K. (2017). Effects of chlorine dioxide fumigation on redox balancing potential of antioxidative ascorbate-glutathione cycle in 'Daw'longan fruit during storage. Scientia Horticulturae, $222,76-83$.

Clayton, M., Biasi, W. V., Agar, I. T., Southwick, S. M., \& Mitcham, E. J. (2006). Sensory quality of Bing sweet cherries following preharvest treatment with hydrogen cyanamide, calcium ammonium nitrate, or gibberellic Acid. HortScience, 41(3), 745-748

Correia, S., Queirós, F., Ribeiro, C., Vilela, A., Aires, A., Barrosa, A.I., Schouten, R., Ana Silva, A.P. \& Gonçalves, B. (2019). Effects of calcium and growth regulators on sweet cherry (Prunus avium L.) quality and sensory attributes at harvest. Scientia Horticulturae, 248, 231-240.

Díaz-Mula, H. M., Castillo, S., Martínez-Romero, D., Valero, D., Zapata, P. J., Guillén, F., \& Serrano, M. (2009). Sensory, nutritive and functional properties of sweet cherry as affected by cultivar and ripening stage. Food Science and Technology International, 15(6), 535-543.

Dong, Y., Zhi, H., \& Wang, Y. (2019). Cooperative effects of preharvest calcium and gibberellic acid on tissue calcium content, quality attributes, and in relation to postharvest disorders of late-maturing sweet cherry. Scientia Horticulturae, 246, 123128.

Einhorn, T. C., Wang, Y., \& Turner, J. (2013). Sweet cherry fruit firmness and postharvest quality of late-maturing cultivars are improved with low-rate, single applications of gibberellic acid. HortScience, 48(8), 1010-1017.

Fortes, A. M., Teixeira, R. T., \& Agudelo-Romero, P. (2015). Complex interplay of hormonal signals during grape berry ripening. Molecules, 20(5), 9326-9343.

Gao, Q. H., Wu, C. S., \& Wang, M. (2013). The jujube (Ziziphus jujuba Mill.) fruit: a review of current knowledge of fruit composition and health benefits. Journal of Agricultural and Food Chemistry, 61(14), 3351-3363.

Gunduz, K., \& Saracoglu, O. (2014). Changes in chemical composition, total phenolic content and antioxidant activities of jujube (Ziziphus jujuba Mill.) fruits at different maturation stages. Acta Scientiarum Polonorum-Hortorum Cultus, 13(2), 187-195.

Gupta, O. P., Siddiqui, S., \& Chauhan, K. S. (1987). Evaluation of various calcium compounds for increasing the shelf life of ber (Ziziphus mauritiana Lamk.) fruit. Indian Journal of Agricultural Research, 21, 65-70.

Han, X., Lu, W., Wei, X., Li, L., Mao, L., \& Zhao, Y. (2018). Proteomics analysis to understand the ABA stimulation of wound suberization in kiwifruit. Journal of Proteomics, 173, 42-51.

Hassanpour, H. (2015). Effect of Aloe vera gel coating on antioxidant capacity, antioxidant enzyme activities and decay in raspberry fruit. LWT-Food Science and Technology, 60(1), 495-501.

Hoagland, P. D., \& Parris, N. (1996). Chitosan/pectin laminated films. Journal of Agricultural and Food Chemistry, 44(7), 19151919.

Kader, A. A., \& Yahia, E. M. (2011). Postharvest biology of tropical and subtropical fruits. In: In: Yahia, E.M. (Ed.), Postharvest Biology and Technology of Tropical and Subtropical Fruits 1. Woodhead Publishing, pp. 79-111.

Keles, H. (2020). Changes of some horticultural characteristics in jujube (Ziziphus jujube Mill.) fruit at different ripening stages. Turkish Journal of Agriculture and Forestry, 44, 391-398.

Khaliq, G., Ramzan, M., \& Baloch, A. H. (2019). Effect of Aloe vera gel coating enriched with Fagonia indica plant extract on physicochemical and antioxidant activity of sapodilla fruit during postharvest storage. Food Chemistry, 286, 346-353.

Lin, L., Tian, S. P., Wan, Y. K., Xu, Y., \& Yao, H. J. (2004). Effects of temperature and atmosphere component on quality of stored jujube fruit. Acta Botanica Sinica-English Edition, 46(8), 928934.

Mahajan, B. C., Tandon, R., Kapoor, S., \& Sidhu, M. K. (2018). Natural coatings for shelf life enhancement and quality maintenance of fresh fruits and vegetables-A review. J. Postharvest Technology, 6(1), 12-26.

Mahmood, Z., Ahmed, I., Saeed, M. U. Q., \& Sheikh, M. A. (2013). Investigation of physico-chemical composition and antimicrobial activity of essential oil extracted from lignincontaining Cupressus sempervirens. BioResources, 8(2), 16251633.

Mannozzi, C., Tylewicz, U., Chinnici, F., Siroli, L., Rocculi, P., Dalla Rosa, M., \& Romani, S. (2018). Effects of chitosan based coatings enriched with procyanidin by-product on quality of fresh blueberries during storage. Food Chemistry, 251, 18-24.

Martínez-Romero, D., Castillo, S., Guillén, F., Díaz-Mula, H. M., Zapata, P. J., Valero, D., \& Serrano, M. (2013). Aloe vera gel coating maintains quality and safety of ready-to-eat pomegranate arils. Postharvest Biology and Technology, 86, 107-112.

Meland, M., Kaiser, C., \& Christensen, J. M. (2014). Physical and chemical methods to avoid fruit cracking in cherry. AgroLife Scientific Journal, 3(1), 177-183.

Ozkan, Y., Ucar, M., Yildiz, K., \& Ozturk, B. (2016). Pre-harvest gibberellic acid $\left(\mathrm{GA}_{3}\right)$ treatments play an important role on 
bioactive compounds and fruit quality of sweet cherry cultivars. Scientia Horticulturae, 211, 358-362.

Ozturk, B., Bektas, E., Aglar, E., Karakaya, O., \& Gun, S. (2018). Cracking and quality attributes of jujube fruits as affected by covering and pre-harvest Parka and GA3 treatments. Scientia Horticulturae, 240, 65-71.

Pharis, R. P., \& King, R. W. (1985). Gibberellins and reproductive development in seed plants. Annual Review of Plant Physiology, 36(1), 517-568.

Pu, Y., Ding, T., Wang, W., Xiang, Y., Ye, X., Li, M., \& Liu, D. (2018). Effect of harvest, drying and storage on the bitterness, moisture, sugars, free amino acids and phenolic compounds of jujube fruit (Zizyphus jujuba cv. Junzao). Journal of the Science of Food and Agriculture, 98(2), 628-634.

Qiuping, Z., \& Wenshui, X. (2007). Effect of 1methylcyclopropene and/or chitosan coating treatments on storage life and quality maintenance of Indian jujube fruit. LWT-Food Science and Technology, 40(3), 404-411.

Reque, P. M., Steffens, R. S., Jablonski, A., Flôres, S. H., Rios, A. D. O., \& de Jong, E. V. (2014). Cold storage of blueberry (Vaccinium spp.) fruits and juice: Anthocyanin stability and antioxidant activity. Journal of Food Composition and Analysis, 33(1), 111-116.

San, B., \& Yildirim, A. N. (2010). Phenolic, alpha-tocopherol, betacarotene and fatty acid composition of four promising jujube (Ziziphus jujuba Miller) selections. Journal of food composition and analysis, 23(7), 706-710.

Sandhya, (2010). Modified atmosphere packaging of fresh produce: current status and future needs. LWT-Food Science and Technology, 43, 381-392.

Sharma, S. K., \& Pratima, P. (2018). Effect of Pre-Harvest Gibberellic Acid and Calcium Application on Post-Harvest Behaviour of Subtropical Peaches. Current Agriculture Research Journal, 6(1), 78-84.

Serra, A. T., Duarte, R. O., Bronze, M. R., \& Duarte, C. M. (2011). Identification of bioactive response in traditional cherries from Portugal. Food Chemistry, 125(2), 318-325.

Sheng, J.P., Luo, Y.B., \& Shen, L. (2003). Storage of Chinese winter jujube fruit. Acta Horticulturae, 620, 203-208.

Siddiq, M., \& Uebersax, M.A. (2012). Jujube and loquat. In: Siddiq (Ed.), Tropical and Subtropical Fruits. Postharvest Physiology, Processing and Packaging. WileyBlackwell, Oxford (United Kingdon).
Souza, K. O., Viana, R. M., de Siqueira Oliveira, L., Moura, C. F. H., \& Miranda, M. R. A. (2016). Preharvest treatment of growth regulators influences postharvest quality and storage life of cashew apples. Scientia Horticulturae, 209, 53-60.

Valero, D., Mirdehghan, S.H., Sayyari, M., \& Serrano, M. (2014). Vapor treatments, chilling, storage, and antioxidants in pomegranates. In: Preedy, V.R. (Ed.), Processing and Impact on Active Components in Food. Academic Press, London, pp. 189-196.

Valverde, J. M., Valero, D., Martínez-Romero, D., Guillén, F., Castillo, S., \& Serrano, M. (2005). Novel edible coating based on Aloe vera gel to maintain table grape quality and safety. Journal of Agricultural and Food Chemistry, 53(20), 78077813.

Wu, C. S., Gao, Q. H., Kjelgren, R. K., Guo, X. D., \& Wang, M. (2013). Yields, phenolic profiles and antioxidant activities of Ziziphus jujube Mill. in response to different fertilization treatments. Molecules, 18(10), 12029-12040.

Yao, S. (2013). Past, present, and future of Jujubes-Chinese dates in the United States. HortScience, 48(6), 672-680.

Yu, L., Jiang, B. P., Luo, D., Shen, X. C., Guo, S., Duan, J. A., \& Tang, Y. P. (2012). Bioactive components in the fruits of Ziziphus jujuba Mill. against the inflammatory irritant action of Euphorbia plants. Phytomedicine, 19(3-4), 239-244.

Zhang, L., Wang, P., Chen, F., Lai, S., Yu, H., \& Yang, H. (2019a). Effects of calcium and pectin methylesterase on quality attributes and pectin morphology of jujube fruit under vacuum impregnation during storage. Food Chemistry, 289, 40-48.

Zhang, J., Li, C., Wei, M., Ge, Y., Tang, Q., Xue, W., Zhang, S., Wang, W., \& Lv, J. (2019b). Effects of trisodium phosphate treatment after harvest on storage quality and sucrose metabolism in jujube fruit. Journal of the Science of Food and Agriculture, 99(12), 5526-5532.

Zhao, Y., Zhu, X., Hou, Y., Wang, X., \& Li, X. (2020). Postharvest nitric oxide treatment delays the senescence of winter jujube (Zizyphus jujuba Mill. cv. Dongzao) fruit during cold storage by regulating reactive oxygen species metabolism. Scientia Horticulturae, 261, 109009. 